\title{
Climate change impacts on growth and carbon balance of forests in Central Europe
}

\author{
Tomáš Hlásny ${ }^{1,3, *}$, Zoltán Barcza ${ }^{2}$, Marek Fabrika ${ }^{4}$, Borbála Balázs ${ }^{2}$, \\ Galina Churkina ${ }^{5}$, Jozef Pajtík ${ }^{1}$, Róbert Sedmák ${ }^{4}$, Marek Turčáni ${ }^{3}$
${ }^{1}$ Department of Ecology and Biodiversity of Forest Ecosystems, National Forest Centre - Forest Research Institute Zvolen, T. G. Masaryka 22, Zvolen, Slovakia
${ }^{2}$ Department of Meteorology, Eötvös Loránd University, 1117 Budapest, Pázmány P. s. 1/A, Hungary
${ }^{3}$ Faculty of Forestry and Wood Sciences, Czech University of Life Sciences Prague, Prague, Kamýcká 129, Czech Republic
${ }^{4}$ Faculty of Forestry, Technical University Zvolen, T. G. Masaryka 54, Zvolen, Slovakia
${ }^{5}$ Institute of Geography, Humboldt University of Berlin, Rudower Chaussee 16, 12489 Berlin, Germany

\begin{abstract}
We analysed climate change impacts on the growth and natural mortality of forest tree species and forest carbon (C) balance along an elevation gradient extending from the Pannonian lowland to the West Carpathian Mountains (Central Europe). Norway spruce Picea abies, European beech Fagus sylvatica, and oak Quercus sp. were investigated for 2 future time periods: 2021-2050 and 2071-2100. The period 1961-1990 was used as reference. Forest growth simulations were based on the SIBYLA tree growth simulator (an empirical model), and C cycle-related simulations were performed using BIOME-BGC (a process-based biogeochemical model). Growth simulations indicated that climate change will substantially affect the growth of spruce and beech, but not of oak, in Central Europe. Growth of spruce and beech in their upper distribution ranges was projected to improve, while drought-induced production decline was projected at the species' receding edges. Beech was the only species projected to decline critically at lower elevations. C cycle simulations performed for the zone of ecological optima of the 3 tree species indicated that these forests are likely to remain net carbon dioxide sinks in the future, although the magnitude of their sequestration capacity will differ. Increasing nitrogen deposition and atmospheric carbon dioxide concentration were projected to greatly affect the forest $\mathrm{C}$ cycle. A multi-model assessment based on SIBYLA and BIOME-BGC simulations performed for the zone of ecological optima suggested that oak production will either remain the same as in the reference period or will increase. Future production of beech seems uncertain and might decline, while spruce production is likely to increase. The results also confirmed the value of multi-model approaches for assessing future forest development under climate change.
\end{abstract}

KEY WORDS: Norway spruce - European beech - Oak · Forest carbon cycle $\cdot$ Tree production · Tree mortality $\cdot$ BIOME-BGC model $\cdot$ SIBYLA tree growth simulator

Resale or republication not permitted without written consent of the publisher

\section{INTRODUCTION}

Climate change-related alterations of the atmosphere's chemical composition, increased temperature, changes in precipitation patterns, as well as subsequent alteration of forest disturbance regimes are anticipated to have profound impacts on forests worldwide (Ainsworth \& Long 2005, Goldblum \& Rigg 2005). Changes in temperature, precipitation, and atmospheric composition are likely to affect the growth and mortality of forest trees (Lenihan et al. 2003, Matala et al. 2005, Battles et al. 2006), and thereby affect the ecological stability of forests. Forest responses to climate change can be both positive and negative, and can vary across latitudinal and altitudinal gradients, bioclimatic zones, and forest types (Lindner et al. 2010). In contrast to other sectors (e.g. agriculture), forests are especially sensitive to climate change because of their long life spans, which do not allow for functional adaptation. 
With respect to the distribution ranges of species, minimum temperatures are particularly important in limiting tree expansion and vitality at greater latitudes and altitudes (Colwell et al. 2008). Therefore, climate change can stimulate tree growth while supporting species expansion toward the poles and at higher elevations (Walther et al. 2002). Increased temperatures moderate climates at higher elevations and latitudes and prolong the growing season, thus improving tree growth, reproduction, and survival. As a consequence, mountain treelines have shifted upwards by as much as $130 \mathrm{~m}$ over the past $50 \mathrm{yr}$ (Walther 2003). Recent observations have also described a climate changerelated downhill shift of plant species optima (Crimmins et al. 2011) as a consequence of increasing water availability that outpaces evaporative demand. However, this can be regarded as a very specific response.

In contrast to the mostly positive responses of trees to climate change at higher latitudes and altitudes, low water availability can interact with high temperatures to limit the growth of a tree species at its lower range limits (Jump et al. 2006, Colwell et al. 2008). Some European forest tree species are in decline at their lower range limits, due to increased mortality and reduced reproduction linked to increasing temperatures and drought stress (Geßler et al. 2007, Peñuelas et al. 2007).

Climate change impacts on Central European forests have rarely been studied. Most previous studies have focused on mountain forests (e.g. Kienast et al. 1996) in the Alpine mountains (e.g. Wieser et al. 2009, Gimmi et al. 2010) and at northern latitudes (e.g. Matala et al. 2003, 2005). Data for impacts on vegetation in Central European planar and colline zones are lacking. Because the results of such studies are often contradictory, especially in the case of carbon (C) cycle simulations (Karjalainen et al. 2003, Davi et al. 2006, Wamelink et al. 2009), and because considerable uncertainty is associated with simulated values (Valle et al. 2009), the applicability of such information for forest management is limited. Based on Austrian forest inventory data and a modelling exercise, Lexer et al. (2000) projected no abrupt forest dieback up to 2050 in Austrian alpine forests, but substantial changes in species composition of natural potential vegetation may occur. Wamelink et al. (2009) used data from European forest monitoring plots to project the changes in C sequestration by European forests. They found a negative trend in $\mathrm{C}$ sequestration in forest soils and a positive trend in tree biomass by 2070 for Central Europe. However, their study did not include data from Slovakia, Czech Republic, Poland, and Hungary. Davi et al. (2006) analysed the sensitivity of $\mathrm{C}$ fluxes to climate change in 6 representative forest ecosystems in Western Europe. These authors found that all ecosystems will remain $\mathrm{C}$ sinks, but that sink strength will slightly decrease for coniferous forests and will increase for deciduous forests. In contrast, Lindner et al. (2010) stated that forests in the temperate continental zone (most of Central Europe) could turn into $\mathrm{C}$ sources in the distant future because of climate change. Similarly, Barcza et al. (2009) suggested that Central European forests, rather than taking up $\mathrm{C}$ on an annual basis, could potentially become $\mathrm{C}$ sources under specific environmental conditions. Other studies have projected sustained but decreasing forest $\mathrm{C}$ sequestration in the future (Karjalainen et al. 2003) or even increased C sequestration in Europe north of $50^{\circ}$ latitude until 2070 (Wamelink et al. 2009).

The main goal of this paper is to analyse impacts of future climate change on tree growth, tree mortality, and $\mathrm{C}$ balance in several Central European forest ecosystems. We focus on Norway spruce Picea abies L., European beech Fagus sylvatica L., and oak Quercus sp. stands distributed along an elevation gradient extending from the Pannonian lowland to the West Carpathian Mountains.

Global processes present at large spatial scales can be observed at smaller scales, where altitudinal control prevails over latitudinal control of vegetation distribution (Jump et al. 2009). We used the diverse natural conditions of the study region as well as its intensive climatic gradient to assess climate-change impacts on the investigated tree species. We are especially concerned with how climate change will affect expansion of species distribution at higher elevations, droughtinduced retraction of distribution and production decline at lower elevations, and shifts in production optima.

We hypothesize that $\mathrm{C}$ sequestration will decrease in response to the expected warming and increased occurrence of drought stress, and that $\mathrm{C}$ sequestration will increase in response to enhanced nutrient availability and, at higher elevations, to prolonged growing seasons. It follows that changes in $\mathrm{C}$ sequestration in response to climate change could be site and species specific. Further, we expect that rising atmospheric nitrogen $(\mathrm{N})$ deposition and carbon dioxide $\left(\mathrm{CO}_{2}\right)$ concentrations will substantially affect the forest $\mathrm{C}$ cycle (e.g. see Norby et al. 2005, Churkina et al. 2009, De Vries \& Posch 2011); N deposition is generally expected to affect forest growth in many ecosystems (Magnani et al. 2007, De Vries et al. 2009, Lindner et al. 2010).

Novel aspects of this study are that it projects and quantifies changes in forest production with relatively dense spatial sampling, and provides a multi-model assessment of forest stand production and $\mathrm{C}$ balance within the presently assumed ecological optima of spruce, beech and oak. In addition, the combined use of empirical and process-based models enhances output robustness (Link \& Barker 2006, Valle et al. 2009) and also stresses model limitations. 


\section{MATERIALS AND METHODS}

\subsection{Study region}

The study region is situated in the Temperate Continental Bioclimatic Zone (Rivas-Martínez et al. 2004). The region extends from the Pannonian lowland in the south, with mostly xerothermophilous vegetation, to the High Tatra Mountains (West Carpathians) in the north, where the upper tree limit lies (see Table 1). Because most Central European forest vegetation zones are present here, this region is useful for investigating climate change-driven processes over a range of forest communities, inferring their expected interactions, and assessing regional changes in forest production and $\mathrm{C}$ balance. The region is located in a vulnerable area, where the strength of climate change might be amplified by a factor of 1.2 to 1.5 relative to the global average (Bartholy et al. 2007). Projected temperature increase for this region by 2100 is 3 to $4^{\circ} \mathrm{C}$. Precipitation is expected to increase by up to $10 \%$ mainly in the winter months, while summer precipitation is expected to decrease by as much as $10 \%$ (Christensen et al. 2007). Mountain regions (especially the High Tatras) are expected to experience even greater temperature increases, although projected precipitation amounts and patterns are subject to considerable uncertainty. Expected northward shifts of storm tracks, which could trigger drought and heat spells in Central Europe (Schär et al. 2004, Giorgi \& Coppola 2007), could directly impact forest vegetation. Forest growth, regeneration, and survival are expected to be constrained, mainly by water scarcity at the xeric limits of the species.

\subsection{Climate models and data post-processing}

The regional climate models (RCMs) ALADIN Climate/CZ, RegCM beta ELU/HU, ALADIN-Climate HMS/HU, and RegCM beta CUNI/CZ with horizontal spatial resolution of $10 \mathrm{~km}$ provided the daily-step series of climate elements for the impact models. The global climate models (GCMs) ARPEGE-Climat (MeteoFrance) (Courtier et al. 1991) and ECHAM5 (Roeckner et al. 2003) provided initial and boundary conditions for the RCMs. The climate scenarios indicate that the mean temperature will increase by $\sim 3.3^{\circ} \mathrm{C}$ in the region, while annual precipitation will decrease by $5 \%$ in the 2071-2100 period, compared to the reference period (1961-1990).

The IPCC SRES A1B scenario (Nakicenovic \& Swart 2000) described the future development of $\mathrm{CO}_{2}$ emissions. The projections were produced for 2 future time periods: 2021-2050 (near future climate) and 20712100 (distant future climate).
Because a systematic over- or underestimation can occur in precipitation scenarios, we used the CRU TS 1.2 data (high-resolution gridded data set of interpolated meteorological observations with monthly time step for the period 1901-2000; Mitchell et al. 2004) and the simulation data from the reference period (19611990) to estimate the bias and correct the future precipitation scenario data. The missing intervals (20082020, 2051-2070) were filled following the method of Morales et al. (2007). Because this method can provide monthly estimates for the transient periods, the $\mathrm{C} 2 \mathrm{~W}$ weather generator (Bürger 1997) was used to create the daily data.

\subsection{Impact models and methods}

\subsubsection{SIBYLA}

The SIBYLA growth simulator (Fabrika \& Durský $2005,2006)$ was used to model climate change impacts on tree production and natural mortality. SIBYLA is an individual-tree, distance-dependent model. It is an empirical, ecological niche-based model that simulates the growth of individual trees and in doing so, evaluates inter- and intraspecific competition among trees. The growth sub-model was originally designed by Pretzsch \& Kahn (1998). Growth responses to respective environmental parameters were formalized according to Kahn (1994). The mortality sub-model was described by Duurský et al. (1996) and Ďurský (1997). Other model routines were not used in this study. SIBYLA was parameterised and validated using forest inventory data from Slovakia and Germany. Because the model's growth and mortality routines are climate sensitive, the simulator should be well suited for modelling the impacts of climate change on forest development.

The simulations were run on virtual sample plots with an average size of $0.25 \mathrm{ha}$. The soil moisture and nutrition regimes represent a plot's surrounding area (5 km circle). The plots were arranged along a gradient crossing through all vegetation zones (VZs) in the study region (Table 1) (Zlatník 1976). We assumed that the vegetation in these zones is currently at a stable state, and we compared this current state with projected changes. All simulations were run under the ALADIN-Climate/CZ climate change scenario.

Average values for production and natural mortality of $40,60,80$, and $100 \mathrm{yr}$ old forest stands (age at beginning of simulation periods) at the end of three $30 \mathrm{yr}$ simulation periods (1961-1990, 2021-2050, 2071-2100) were investigated in relation to the VZs. The growth of each species was simulated at all plots within the range of species-specific limiting environmental conditions. 
Table 1. Description of plots used for tree growth simulations and species simulated. Dominant species are given with the assumption of natural tree species distribution; species cultivation range is different in most cases. $T$ : air temperature, $P$ : total precipitation (annual means, 1961-1990), O: oak Quercus sp., B: European beech Fagus sylvatica, S: Norway spruce Picea abies

\begin{tabular}{|lcccccc|}
\hline $\begin{array}{l}\text { Vege- } \\
\text { tation } \\
\text { zone }\end{array}$ & $\begin{array}{c}\text { Elevation } \\
\text { (m a.s.l.) }\end{array}$ & $\begin{array}{c}\text { Dominant } \\
\text { species }\end{array}$ & $\begin{array}{c}\text { Plot } \\
\text { elevation } \\
(\mathrm{m} \text { a.s.l. })\end{array}$ & $\begin{array}{c}T \\
\left({ }^{\circ} \mathrm{C}\right)\end{array}$ & $\begin{array}{c}P \\
(\mathrm{~mm})\end{array}$ & $\begin{array}{c}\text { Simulated } \\
\text { species }\end{array}$ \\
\hline 1st & $\leq 300$ & Oak & 172 & 9.0 & 543 & O-B \\
2nd & $200-500$ & Beech-Oak & 248 & 7.8 & 574 & O-B \\
3rd & $300-700$ & Oak-Beech & 521 & 7.5 & 592 & O-B \\
4th & $400-800$ & Beech & 430 & 7.5 & 680 & O-B-S \\
& & & 547 & 7.2 & 695 & O-B-S \\
5th & $500-1000$ & Fir-Beech & 640 & 5.1 & 820 & O-B-S \\
& & & 681 & 5.7 & 680 & O-B-S \\
6th & $900-1300$ & Spruce-Fir-Beech & 1100 & 2.8 & 860 & O-B-S \\
& & & 1146 & 3.1 & 905 & O-B-S \\
7th & $1250-1550$ & Spruce & 1367 & 1.3 & 1040 & B-S \\
8th & $\geq 1550$ & Dwarf pine & 1633 & 0.9 & 910 & B-S \\
\hline
\end{tabular}

The simulations were run under the following conditions: (1) no management is applied except for removal of dead trees; (2) only natural tree mortality occurs (no disturbances); (3) stand density is 0.9; and (4) mean site class and mean volume level are used.

The following procedures were applied to allow for statistical analysis of simulation outputs: (1) 10 random stand structures with altered tree distribution were generated for each plot; (2) Each growth simulation was run $10 \times$ for each stand structure, and tree increment and mortality were stochastically altered each time; and (3) Growth of each species was simulated within a range of tree species compositions, including monospecific composition, which naturally occur in a given VZ.

The following quantities were investigated: (1) total volume production, calculated as the sum of growing stock at the end of the simulation period, and mortality during the simulation period; (2) change in growing stock, calculated as the difference between the growing stock at the end and that at the beginning of the $30 \mathrm{yr}$ simulation periods; and (3) cumulative volume of dead trees, calculated as the sum of naturally dying trees during the simulation period.

The relative change between the growing stock at the end and that at the beginning of the $30 \mathrm{yr}$ simulation periods was calculated as the difference between final and initial stock relative to the initial growing stock (\%). Because the initial growing stock was uniform for all $30 \mathrm{yr}$ simulations, the temporal evolution of the relative change in growing stock can be directly translated into absolute growing stock (stem and root) increment.
The final analysis examined the differences in mean values of total volume production, change in growing stock, and cumulative volume of dead trees at the end of the simulation periods in all plots within the respective VZs. This design allowed us to include a large part of the variability in natural conditions for each VZ. To allow for broader use of the results, we investigated relative rather than absolute changes.

\subsubsection{BIOME-BGC}

BIOME-BGC is a process-based, mechanistic biogeochemical model for simulating $\mathrm{C}, \mathrm{N}$, and water fluxes in different terrestrial ecosystems, such as deciduous and evergreen forests, grasslands, and shrublands (White et al. 2000, Churkina et al. 2003). Because BIOME-BGC deals with the $\mathrm{N}$ cycle, the effect of changing $\mathrm{N}$ deposition can be included in the analysis. The model requires daily meteorological data, geomorphologic and soil characteristics, and ecophysiological parameters (see White et al. 2000 for details).

BIOME-BGC 4.1.1 with modifications described by Trusilova et al. (2009) was used to simulate the present and future $\mathrm{C}$ cycle of 3 unmanaged forest stands (Table 2). Intensive monitoring plots (IMPs) operated within the European monitoring network (ICP Forests) since 1995 were the subject of analysis.

Forest $\mathrm{C}$ balance was described by the changing $\mathrm{C}$ stocks (living biomass, dead wood, litter, soil organic $\mathrm{C}$ ) and by the main $\mathrm{C}$ fluxes of the ecosystem from the atmospheric viewpoint (gross primary production: GPP, total ecosystem respiration: $\mathrm{R}_{\text {eco }}$ and net ecosystem exchange: NEE, where NEE $=\mathrm{R}_{\text {eco }}-\mathrm{GPP}$; Churkina et al. 2003). The relative change in the growing stock during the $30 \mathrm{yr}$ simulation periods and total volume production were also analysed. Forest age was taken into account following the method of Tatarinov \& Cienciala (2006).

We used the model's spin-up option to estimate initial values of the soil $\mathrm{C}$ and $\mathrm{N}$ pools (see Churkina et al. 2003 for details). We used CRU TS 1.2 data for the spinup phase. The MT-CLIM model (Thornton \& Running 1999, Tatarinov \& Cienciala 2006) was used for estimating the missing meteorological variables (mean daytime vapour pressure deficit, mean daytime global radiation, and mean daytime temperature). Historical $\mathrm{CO}_{2}$ mixing ratio data were estimated based on the Law Dome ice core measurements and Mauna Loa 
Table 2. Description of intensive monitoring plots used for carbon cycle simulations. $P$ and $T$ : mean annual precipitation totals and mean annual air temperature, respectively (1961-1990). Tree age is in 2010

\begin{tabular}{|c|c|c|c|c|c|c|c|}
\hline Plot ID (local name) & Dominant species & Latitude & Longitude & $\begin{array}{c}\text { Elevation } \\
\text { (m a.s.l.) }\end{array}$ & $\begin{array}{l}\text { Tree age } \\
\text { (yr) }\end{array}$ & $T\left({ }^{\circ} \mathrm{C}\right)$ & $P(\mathrm{~mm})$ \\
\hline IMP 54-201 (Čifáre) & Turkey oak Quercus cerris & $48^{\circ} 12^{\prime} 45^{\prime \prime}$ & $18^{\circ} 23^{\prime} 16^{\prime \prime}$ & 206 & 85 & 9.3 & 540 \\
\hline IMP 54-206 (Turová) & European beech Fagus sylvatica & $48^{\circ} 37^{\prime} 58^{\prime \prime}$ & $19^{\circ} 02^{\prime} 49^{\prime \prime}$ & 575 & 82 & 7.1 & 675 \\
\hline IMP 54-203 (Jasenie) & Norway spruce Picea abies & $48^{\circ} 55^{\prime} 31^{\prime \prime}$ & $19^{\circ} 29^{\prime} 15^{\prime \prime}$ & 1250 & 71 & 3.2 & 870 \\
\hline
\end{tabular}

observations (Keeling \& Whorf 2004). The SRES data were used for estimating future $\mathrm{CO}_{2}$ concentration (A1B scenario; Nakicenovic \& Swart 2000). N-deposition data are not available for the study region; thus, we used model outputs for reconstructing the past $\mathrm{N}$ deposition (Churkina et al. 2009). Future evolution of $\mathrm{N}$ deposition was estimated based on a data set provided by Dentener (2006).

Continuous stand development was simulated up to 2100 for all 3 plots, following clear-cut in the first half of the 20th century (Design 1). In addition, simulations starting in 1901, 1961, and 2011 were performed to allow stand age to reach $60 \mathrm{yr}$ at the beginning of each 30 yr simulation period (1961-1990, 2021-2050, 20712100) (Design 2). The continuous stand development simulations were run under $4 \mathrm{CO}_{2}$ concentrations and $\mathrm{N}$-deposition scenarios combined with the RCMs. The scenarios were as follows: (1) elevated atmospheric $\mathrm{CO}_{2}$ concentration and $\mathrm{N}$ deposition as described above (baseline), (2) $\mathrm{CO}_{2}$ concentration held at year 2000 level (FC), (3) N deposition held at year 2000 level (FN), and (4) $\mathrm{CO}_{2}$ concentration and $\mathrm{N}$ deposition held at year 2000 level (FN-FC).

The simulations under Design 2 were performed using only the ALADIN Climate/CZ climate model combined with the baseline $\mathrm{CO}_{2}$ concentration and $\mathrm{N}$ deposition scenario. Such a design allowed us to properly compare BIOME-BGC outputs with SIBYLA simulations and to conduct a multi-model assessment of future forest production.

ALADIN Climate/CZ also represents well the ensemble of the 4 RCMs that were previously mentioned. Design 1 allowed us to separate the effect of $\mathrm{CO}_{2}$ concentration from that of $\mathrm{N}$ deposition on forest $\mathrm{C}$ balance. In this design, changes in climate remained mixed with the inherent development of forest biomass over the course of forest development (age effect). Design 2 aimed to quantify only the effect of climate change.

Model calibration used plot-specific data on stem, root, and leaf C content for the period 1997-2008. The ecophysiological parameterisation was based on species-specific parameters (Pietsch et al. 2005). Cienciala \& Tatarinov (2006) proposed that BIOME-BGC model calibration for forests should involve only 2 site para- meters: biological (symbiotic and asymbiotic) $\mathrm{N}$ fixation and effective soil depth. The maximum likelihood method (Hollinger \& Richardson 2005) was used for estimating these parameters. At the site IMP 54-206 (beech), an additional ecophysiological model parameter ('ALLOCATION: new root C: new stem C'; White et al. 2000) was also modified to resolve the discrepancy between measured and simulated $\mathrm{C}$ pools.

Constant mortality (equal to mortality during the reference period) was primarily used in C cycle simulations, following the logic of BIOME-BGC 4.1.1 (Pietsch et al. 2005). With regard to the high sensitivity of BIOME-BGC to mortality as well as to the unrealistic assumption of stable forest mortality under climate change, we also performed simulations with a modified version of the model using mortality that varied annually; annual variations in mortality were provided by the SIBYLA model for each species.

\subsection{Model comparison}

We compared the relative values of total volume production and change in forest growing stock produced by the SIBYLA and BIOME-BGC models in the zone of present ecological optima of the species. To cope with different experimental designs, we used only those SIBYLA plots where natural conditions are closest to BIOME-BGC plots for the comparisons (the selected plots were in the 1st VZ for oak, the 3rd VZ for beech, and the 7 th VZ for spruce). To ensure the consistency of BIOME-BGC and SIBYLA outputs, we used only those simulations that were driven by the ALADIN Climate/CZ RCM under the baseline $\mathrm{CO}_{2}$ concentration and N-deposition scenario.

Simulations of $60 \mathrm{yr}$ old forest stands (initial age at the beginning of $30 \mathrm{yr}$ simulation periods) were compared. A weighted average of 3 model simulations was used to reach a balanced influence of the 2 models on the estimated general trend of future forest production. These simulations included BIOME-BGC simulations based on $60 \mathrm{yr}$ old forests at the beginning of the $30 \mathrm{yr}$ periods (Design 2) with constant mortality $(w=0.25)$, BIOME-BGC simulations (Design 2) with dynamic mortality ( $w=0.25)$, and SIBYLA simulations $(w=0.5)$. 

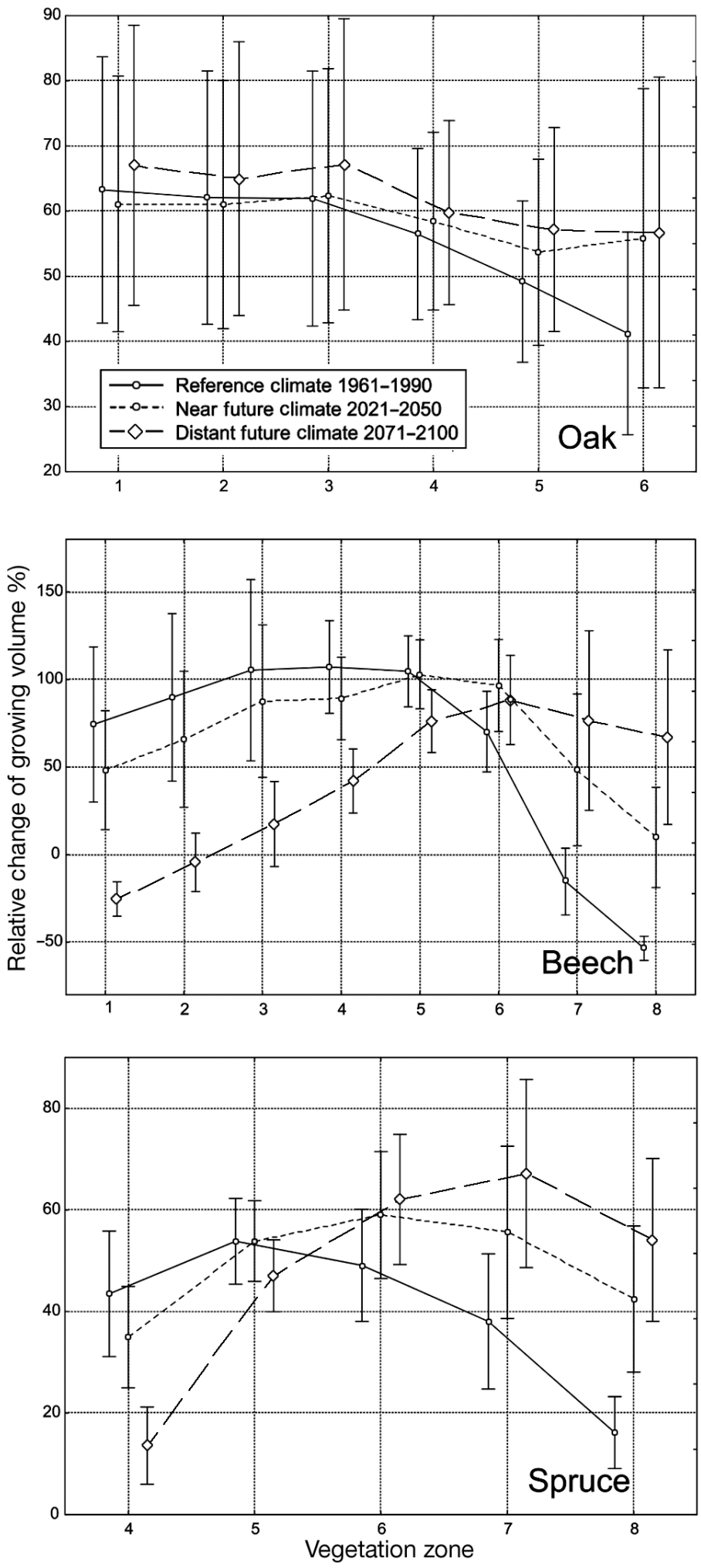

Fig. 1. Relative changes in growing volume over $30 \mathrm{yr}$ simulation periods (1961-1990, 2021-2050, 2071-2100) across the vegetation zones under the ALADIN Climate/CZ climate change scenario. Vertical bars: $97.5 \%$ confidence bands $(\alpha=5 \%)$
In the case of SIBYLA simulations, the initial volume of all simulated stands was held constant at the beginning of all simulation periods, i.e. the volume differed by age and species, but not by time period. However, this must be regarded as an assumption because such stands reach a given age under different climates. In contrast, the BIOME-BGC simulations described below are not burdened by this assumption, because stand development is always simulated from Age 0 . Although this difference affects the comparison of relative changes in growing stock between the SIBYLA and BIOME-BGC models, it should not greatly influence the results.

In the case of oak, we investigated the $\mathrm{C}$ balance of a Turkey oak Quercus cerris stand, but we used a growth simulator that was parameterised for oak in general (Quercus sp.); this can produce some inconsistencies, because oak species can differ in their responses to climate change (e.g. see Wamelink et al. 2009).

\section{RESULTS}

\subsection{Climate change impacts on forest tree growth and mortality}

The growing stock of oak stands modelled under the reference climate in VZs 1 to 3 was constant, while the growing stock markedly decreased in higher elevation zones dominated by beech and fir (Fig. 1). Changes induced by climate change in oak production within its current ecological optimum (VZs 1 to 3 ) were negligible, fluctuating around the reference level by \pm 1 to $3 \%$ in both the near future and distant future (Fig. 2). The production was projected to improve by up to $8 \%$ in VZ 6, which is, however, beyond the limit of present oak distribution. The mortality response was more or less stable throughout all VZs, or even decreasing in VZ 1 and 2.

Changes in the production of spruce and beech exhibited similar responses across the VZs (Fig. 1). Production of both species was subject to decline at the receding edge (i.e. at the lower part of the distribution range of the species), while a significant increase in production was projected at the upper edge at higher elevations. The mortality pattern was less clear and varied between the species (Fig. 2).

In the reference period, the production optimum for beech was in VZs 3 to 5 (Fig. 1). The simulated change in growing volume in VZs 7 to 8 was negative, indicating that mortality was greater than the increment. This corresponds with the current beech-free status of these zones. In the near future, beech production was projected to decline by 5 to $10 \%$ in VZs 1 to 2, where various oak species naturally dominate (mainly Quercus 

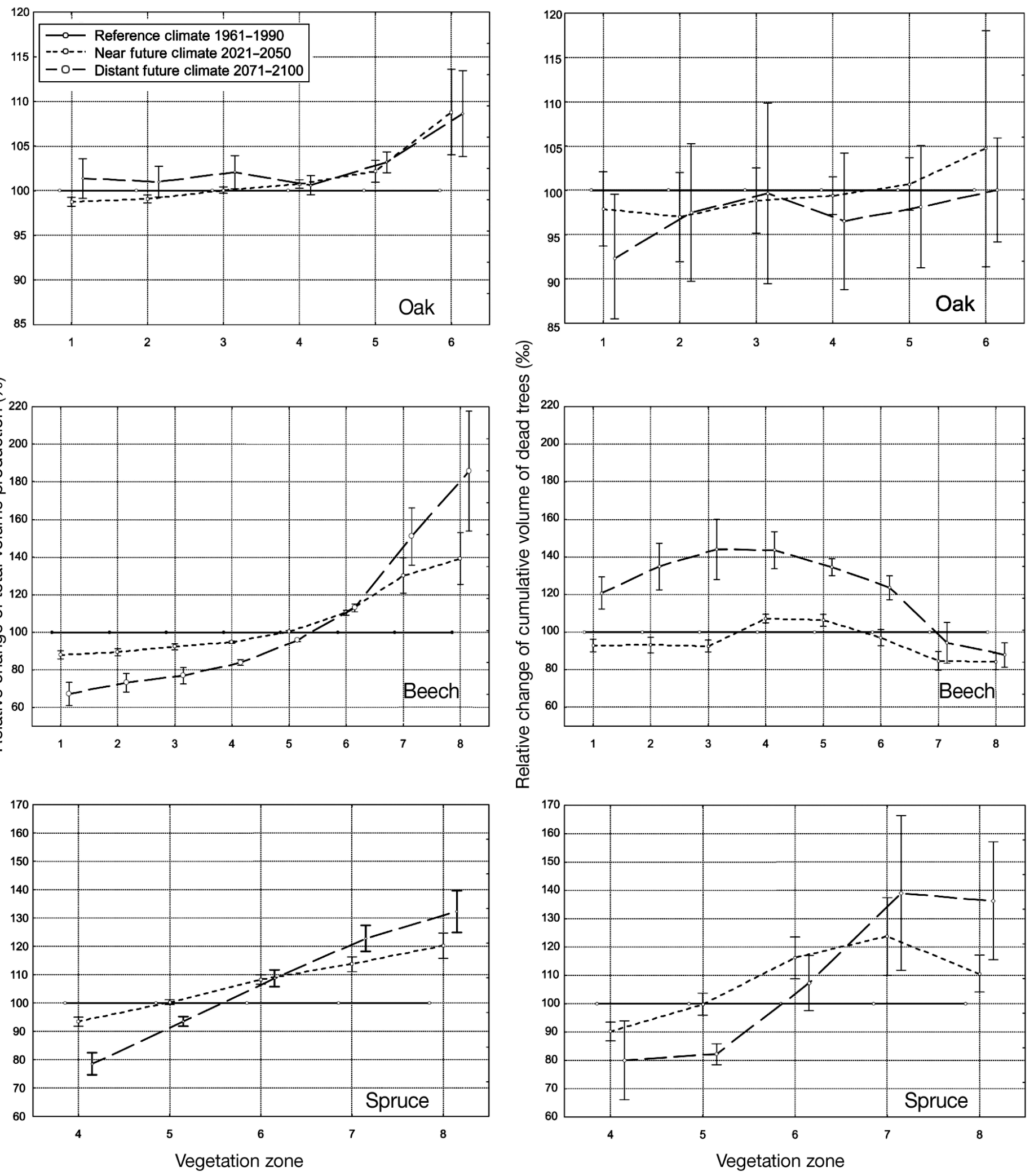

Fig. 2. Relative responses of oak, beech, and spruce production and natural mortality across the vegetation zones under the ALADIN Climate/CZ climate change scenario. Vertical bars: $97.5 \%$ confidence bands $(\alpha=5 \%)$ 

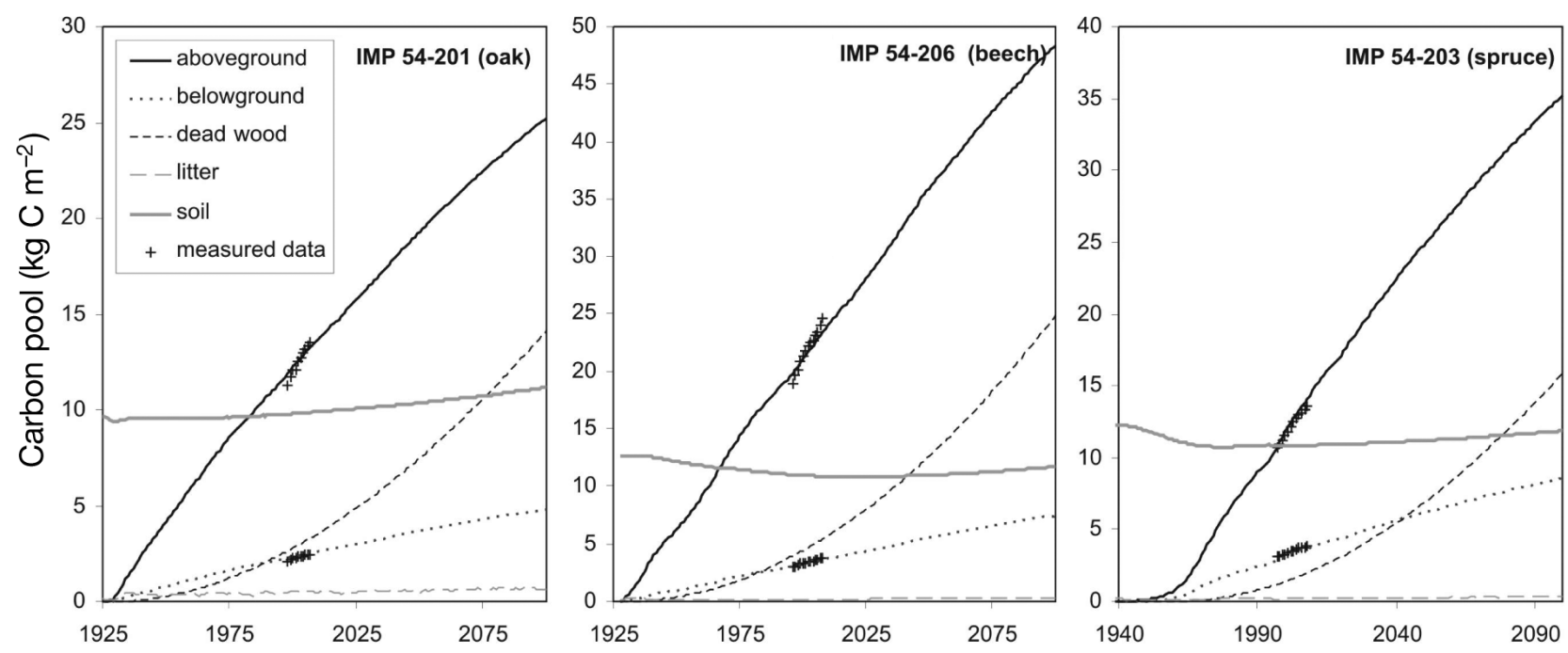

Fig. 3. Average changes in the main carbon pools of the 3 forest stands with the baseline $\mathrm{CO}_{2}$ concentration and $\mathrm{N}$-deposition scenarios based on $4 \mathrm{RCMs}$

cerris, Q. robur, and Q. petraea). A decrease in beech production by as much as $10 \%$ was also projected in VZs 3 to 4 , which is presently the ecological optimum for beech. Production in the 5th VZ remained similar to that of the reference period, while an improvement of 15 to $40 \%$ was projected in VZs 6 to 8 . The change in growing stock in the 8 th VZ was zero (versus $-150 \%$ in the reference climate); thus, the climate was projected to continue to critically limit the growth of beech in that VZ (without consideration of edaphic limitations). The small gains in VZs 6 to 7 prevented the increase from compensating for the reduced production in the dominant VZs 3 to 4 . The mortality response was relatively stable, and varied around the reference level by \pm 4 to $5 \%$ throughout all VZs.

Beech production response in the distant future corresponded to that of the near future, except that it was more pronounced. The 1st and 2nd VZs were critical, because the differences between the final and initial stock volumes turned negative. Reduction in the growing stock by as much as $50 \%$ compared to the beginning of the simulation period, along with an increase in natural mortality by up to $30 \%$, indicated a radical, drought-induced reduction of beech distribution in the distant future. The mortality significantly increased (20 to $40 \%$ ) in VZs 1 to 6 , while it decreased in the marginal VZs 7 to 8 . The shape of this response lacks reasonable ecological interpretation.

In the case of spruce, the simulations indicated monotonic increases in both spruce production and natural mortality across all VZs. Compared to the reference period, production was projected to decline in VZs 4 to 5 (which represent spruce's production optimum in the reference period; Fig. 1) but increase in VZs 6 to 8. This trend was projected to be more pro- nounced in the distant future than in the near future. Increased production in VZs 6 to 7 , which are the VZs with the highest proportion of spruce, could positively influence regional forest production. The production optimum for spruce was projected to shift in the distant future from the 5th VZ (the reference) to the 6th to 7 th VZ. This tendency was accompanied by an increasing rate of spruce mortality in VZs 6 to 8, while reduced mortality was projected in VZs 4 to 5 . In contrast to beech, the change in spruce growing stock remained positive, even at its present lower distribution range (4th VZ).

\subsection{Climate change impacts on forest $\mathrm{C}$ balance}

\subsubsection{Continuous stand development with constant mortality (Design 1)}

The content of the main $\mathrm{C}$ pools increased continuously since the recovery period that followed the disturbance (clear-cut) event in the 1920s and 1930s for all investigated species. The simulated values compared well with the measured data, although there were minor deviations of modelled values from observed values for above-ground biomass (Fig. 3). However, because the maximum likelihood method used for the calibration secures the unbiased simulation during the calibration period, overall there is no over- or underestimation of the $\mathrm{C}$ pools.

During stand development of oak, stem and root increments were estimated to decrease by $\sim 10 \%$ in the near future and by $\sim 30 \%$ in the distant future. In the case of beech, stem and root increments were projected to remain essentially unchanged in the near 
Table 3. Carbon pool increment and carbon flux $\left(\mathrm{g} \mathrm{C} \mathrm{m}{ }^{-2} \mathrm{yr}^{-1}\right.$, mean \pm SD) for the reference (1961-1990), near-future (20212050), and distant-future (2071-2100) climate periods under different simulation designs. Age 60: initial age 60; ALA: ALADIN Climate/CZ; IMP: intensive monitoring plot, SI: stem increment, RI: root increment, GPP: gross primary production, $\mathrm{R}_{\text {eco }}$ total ecosystem respiration, NEE: net ecosystem exchange

\begin{tabular}{|c|c|c|c|c|c|c|}
\hline Simulation & Period & SI & RI & GPP & $\mathrm{R}_{\text {eco }}$ & NEE \\
\hline $\begin{array}{l}\text { IMP 54-201 (Čifáre), Oak } \\
\text { Continuous simulation 1925-2100, } \\
4 \text { RCMs, Constant mortality }\end{array}$ & $\begin{array}{l}1961-1990 \\
2021-2050 \\
2071-2100\end{array}$ & $\begin{array}{l}160 \pm 22 \\
142 \pm 26 \\
111 \pm 26\end{array}$ & $\begin{array}{l}30 \pm 4 \\
27 \pm 5 \\
21 \pm 5\end{array}$ & $\begin{array}{r}964 \pm 124 \\
1109 \pm 147 \\
1172 \pm 138\end{array}$ & $\begin{aligned} 759 & \pm 66 \\
917 & \pm 102 \\
1009 & \pm 106\end{aligned}$ & $\begin{array}{l}-204 \pm 69 \\
-192 \pm 75 \\
-163 \pm 63\end{array}$ \\
\hline $\begin{array}{l}\text { Continuous simulation 1925-2100, } \\
\text { ALA, Constant mortality }\end{array}$ & $\begin{array}{l}1961-1990 \\
2021-2050 \\
2071-2100\end{array}$ & $\begin{array}{l}160 \pm 22 \\
153 \pm 33 \\
119 \pm 27\end{array}$ & $\begin{array}{l}30 \pm 4 \\
29 \pm 6 \\
23 \pm 5\end{array}$ & $\begin{array}{r}964 \pm 124 \\
1190 \pm 167 \\
1266 \pm 127\end{array}$ & $\begin{aligned} 759 & \pm 66 \\
987 & \pm 106 \\
1091 & \pm 102\end{aligned}$ & $\begin{array}{l}-204 \pm 69 \\
-203 \pm 83 \\
-175 \pm 76\end{array}$ \\
\hline Age 60, ALA, Constant mortality & $\begin{array}{l}1961-1990 \\
2021-2050 \\
2071-2100\end{array}$ & $\begin{array}{l}133 \pm 19 \\
185 \pm 36 \\
181 \pm 29\end{array}$ & $\begin{array}{l}25 \pm 4 \\
35 \pm 7 \\
34 \pm 6\end{array}$ & $\begin{array}{r}910 \pm 105 \\
1236 \pm 182 \\
1358 \pm 148\end{array}$ & $\begin{aligned} 734 & \pm 65 \\
995 & \pm 108 \\
1107 & \pm 97\end{aligned}$ & $\begin{array}{l}-176 \pm 51 \\
-241 \pm 94 \\
-251 \pm 83\end{array}$ \\
\hline Age 60, ALA, Dynamic mortality & $\begin{array}{l}1961-1990 \\
2021-2050 \\
2071-2100\end{array}$ & $\begin{array}{l}128 \pm 28 \\
217 \pm 48 \\
185 \pm 54\end{array}$ & $\begin{array}{l}24 \pm 5 \\
41 \pm 9 \\
35 \pm 10\end{array}$ & $\begin{array}{l}1150 \pm 158 \\
1686 \pm 203 \\
1760 \pm 226\end{array}$ & $\begin{array}{r}991 \pm 130 \\
1427 \pm 155 \\
1528 \pm 180\end{array}$ & $\begin{array}{l}-159 \pm 75 \\
-259 \pm 84 \\
-233 \pm 106\end{array}$ \\
\hline $\begin{array}{l}\text { IMP 54-206 (Turová), Beech } \\
\text { Continuous simulation 1928-2100, } \\
4 \text { RCMs, Constant mortality }\end{array}$ & $\begin{array}{l}1961-1990 \\
2021-2050 \\
2071-2100\end{array}$ & $\begin{array}{l}310 \pm 57 \\
309 \pm 76 \\
232 \pm 48\end{array}$ & $\begin{array}{l}49 \pm 9 \\
49 \pm 12 \\
37 \pm 8\end{array}$ & $\begin{array}{r}935 \pm 159 \\
1154 \pm 212 \\
1179 \pm 144\end{array}$ & $\begin{array}{l}597 \pm 59 \\
764 \pm 98 \\
864 \pm 5\end{array}$ & $\begin{array}{l}-338 \pm 105 \\
-390 \pm 125 \\
-314 \pm 94\end{array}$ \\
\hline $\begin{array}{l}\text { Continuous simulation 1928-2100, } \\
\text { ALA, Constant mortality }\end{array}$ & $\begin{array}{l}1961-1990 \\
2021-2050 \\
2071-2100\end{array}$ & $\begin{array}{l}310 \pm 57 \\
273 \pm 89 \\
223 \pm 58\end{array}$ & $\begin{array}{l}49 \pm 9 \\
42 \pm 14 \\
34 \pm 9\end{array}$ & $\begin{array}{r}935 \pm 159 \\
1063 \pm 244 \\
1149 \pm 170\end{array}$ & $\begin{array}{l}597 \pm 59 \\
724 \pm 113 \\
843 \pm 68\end{array}$ & $\begin{array}{l}-338 \pm 105 \\
-339 \pm 144 \\
-306 \pm 110\end{array}$ \\
\hline Age 60, ALA, Constant mortality & $\begin{array}{l}1961-1990 \\
2021-2050 \\
2071-2100\end{array}$ & $\begin{array}{l}285 \pm 58 \\
317 \pm 96 \\
326 \pm 77\end{array}$ & $\begin{array}{l}44 \pm 9 \\
49 \pm 15 \\
50 \pm 12\end{array}$ & $\begin{array}{r}957 \pm 163 \\
1088 \pm 268 \\
1193 \pm 219\end{array}$ & $\begin{array}{l}614 \pm 59 \\
707 \pm 120 \\
786 \pm 81\end{array}$ & $\begin{array}{l}-343 \pm 108 \\
-381 \pm 161 \\
-406 \pm 145\end{array}$ \\
\hline Age 60, ALA, Dynamic mortality & $\begin{array}{l}1961-1990 \\
2021-2050 \\
2071-2100\end{array}$ & $\begin{array}{l}201 \pm 51 \\
225 \pm 93 \\
215 \pm 68\end{array}$ & $\begin{array}{l}31 \pm 8 \\
35 \pm 15 \\
34 \pm 11\end{array}$ & $\begin{array}{l}1172 \pm 167 \\
1330 \pm 250 \\
1443 \pm 196\end{array}$ & $\begin{aligned} 895 & \pm 67 \\
1040 & \pm 121 \\
1136 & \pm 84\end{aligned}$ & $\begin{array}{l}-277 \pm 110 \\
-290 \pm 150 \\
-307 \pm 132\end{array}$ \\
\hline $\begin{array}{l}\text { IMP 54-203 (Jasenie), Spruce } \\
\text { Continuous simulation 1939-2100, } \\
4 \text { RCMs, Constant mortality }\end{array}$ & $\begin{array}{l}1961-1990 \\
2021-2050 \\
2071-2100\end{array}$ & $\begin{array}{l}240 \pm 60 \\
245 \pm 20 \\
190 \pm 23\end{array}$ & $\begin{array}{l}70 \pm 18 \\
58 \pm 12 \\
43 \pm 12\end{array}$ & $\begin{array}{l}1371 \pm 417 \\
2012 \pm 88 \\
2155 \pm 84\end{array}$ & $\begin{array}{l}1074 \pm 322 \\
1676 \pm 82 \\
1882 \pm 64\end{array}$ & $\begin{array}{l}-297 \pm 109 \\
-336 \pm 45 \\
-273 \pm 49\end{array}$ \\
\hline $\begin{array}{l}\text { Continuous simulation 1939-2100, } \\
\text { ALA, Constant mortality }\end{array}$ & $\begin{array}{l}1961-1990 \\
2021-2050 \\
2071-2100\end{array}$ & $\begin{array}{l}240 \pm 60 \\
244 \pm 23 \\
188 \pm 24\end{array}$ & $\begin{array}{l}70 \pm 18 \\
59 \pm 14 \\
42 \pm 14\end{array}$ & $\begin{array}{l}1371 \pm 417 \\
2020 \pm 99 \\
2168 \pm 82\end{array}$ & $\begin{array}{l}1074 \pm 322 \\
1683 \pm 100 \\
1895 \pm 58\end{array}$ & $\begin{array}{l}-297 \pm 109 \\
-337 \pm 55 \\
-273 \pm 57\end{array}$ \\
\hline Age 60, ALA, Constant mortality & $\begin{array}{l}1961-1990 \\
2021-2050 \\
2071-2100\end{array}$ & $\begin{array}{l}228 \pm 15 \\
278 \pm 26 \\
288 \pm 42\end{array}$ & $\begin{array}{l}52 \pm 7 \\
67 \pm 17 \\
65 \pm 25\end{array}$ & $\begin{array}{l}1621 \pm 71 \\
2097 \pm 119 \\
2498 \pm 159\end{array}$ & $\begin{array}{l}1314 \pm 44 \\
1719 \pm 113 \\
2099 \pm 77\end{array}$ & $\begin{array}{l}-308 \pm 35 \\
-378 \pm 66 \\
-399 \pm 118\end{array}$ \\
\hline Age 60, ALA, Dynamic mortality & $\begin{array}{l}1961-1990 \\
2021-2050 \\
2071-2100\end{array}$ & $\begin{array}{l}180 \pm 58 \\
178 \pm 37 \\
171 \pm 48\end{array}$ & $\begin{array}{l}44 \pm 23 \\
42 \pm 12 \\
41 \pm 18\end{array}$ & $\begin{array}{l}2025 \pm 124 \\
2517 \pm 105 \\
2996 \pm 95\end{array}$ & $\begin{array}{l}1691 \pm 94 \\
2185 \pm 130 \\
2655 \pm 111\end{array}$ & $\begin{array}{l}-334 \pm 88 \\
-332 \pm 63 \\
-340 \pm 91\end{array}$ \\
\hline
\end{tabular}

future but to decrease by $25 \%$ in the distant future. In the case of spruce, stem increment was projected to remain unchanged in the near future, while root increment was projected to decrease by $16 \%$. According to projections for the distant future, stem increment will decrease by $26 \%$ while root increment will decrease by as much as $40 \%$ relative to the reference period (see Table 3 and Fig. 4 for stem increments).

GPP and $R_{\text {eco }}$ were projected to increase after the year 2000 for all 3 plots (Table 3). NEE, which represents the small residual of the 2 large fluxes of GPP and $\mathrm{R}_{\text {eco, }}$ showed a slight tendency to increase for all species, indicating lower $\mathrm{C}$ uptake in the future (Fig. 4). C sequestration was projected to increase for beech and spruce in the near future but to decrease in the distant future. The results indicate that the forests are likely to remain net $\mathrm{C}$ sinks, assuming that they continue to develop to the age of 160 to $180 \mathrm{yr}$ (they would reach those ages in 2100 ) without any disturbances.

To separate the effects of $\mathrm{N}$ deposition and $\mathrm{CO}_{2}$ fertilization, we simulated continuous growth of the forest stands under alternative $\mathrm{CO}_{2}$-concentration and $\mathrm{N}$ deposition scenarios: FC, FN, and FN-FC (see section 2.3). Fig. 4 shows differences between simulations of stem increment and NEE under these different $\mathrm{CO}_{2}$ concentration and N-deposition scenarios. 


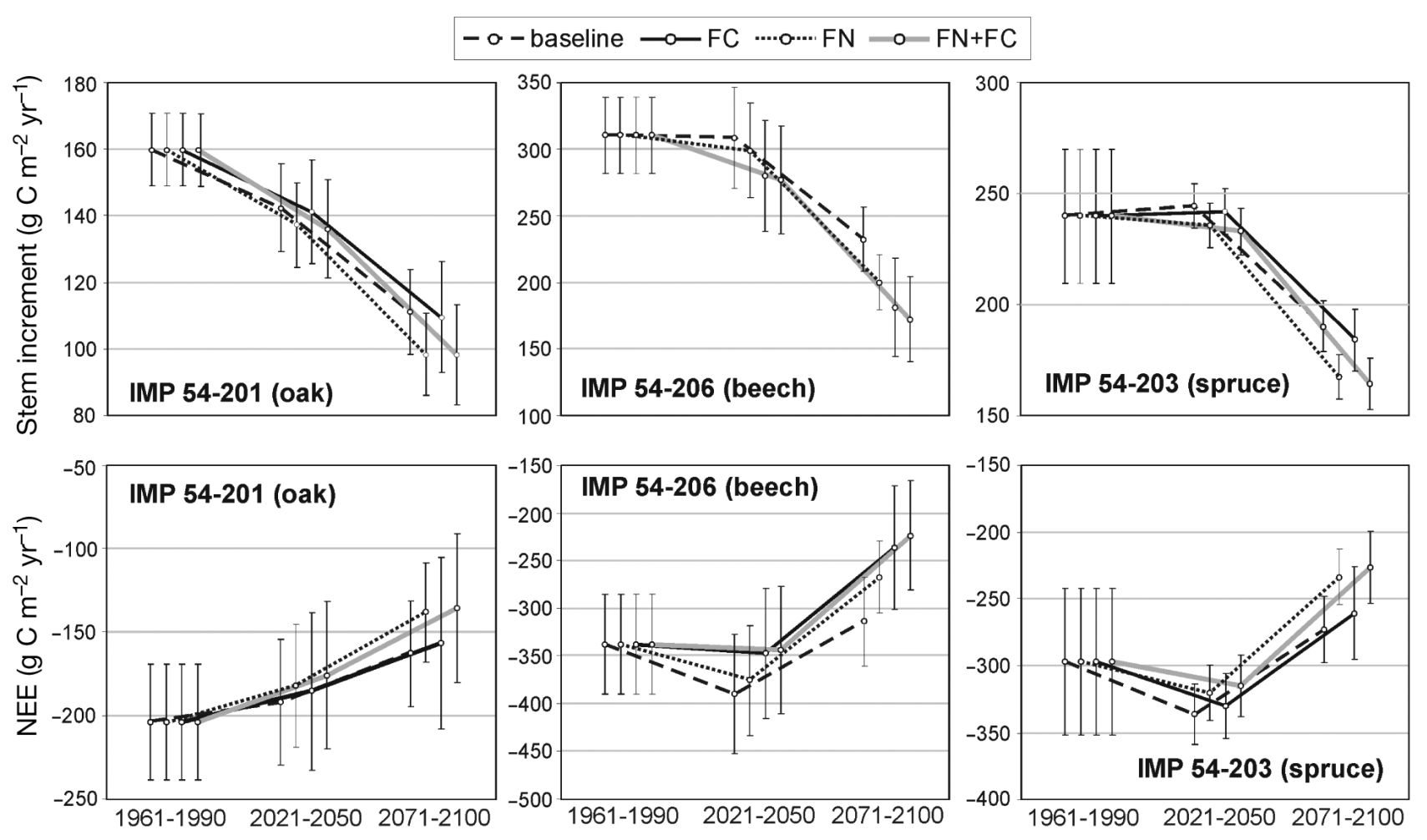

Fig. 4. Average stem increment ( $\mathrm{g} \mathrm{C} \mathrm{m}^{-2} \mathrm{yr}^{-1}$; upper plots) and mean net carbon flux ( $\mathrm{NEE} ; \mathrm{g} \mathrm{C} \mathrm{m}^{-2} \mathrm{yr}^{-1}$; lower plots) for the reference period, near future, and distant future based on the different $\mathrm{CO}_{2}$ concentration and $\mathrm{N}$-deposition scenarios and $4 \mathrm{RCMs}$ (see 2.3. for scenario descriptions). Baseline: elevated atmospheric $\mathrm{CO}_{2}$ concentration and $\mathrm{N}$ deposition; $\mathrm{FC}$ : $\mathrm{CO}_{2}$ concentration held at year 2000 level $_{i}$ FN: N deposition held at year 2000 level. Error bars: SD

For oak, both stem increment and NEE suggested that the model simulations under the FC scenario are closer to the baseline than to the FN scenario. This indicates that $\mathrm{N}$ deposition alone can explain the difference between the baseline and the FN-FC scenario. Thus, soils in the oak plot are probably N limited.

In contrast, the simulations at spruce and beech plots under the FC scenario were very similar to those under the FN-FC scenario. Thus, the impact of $\mathrm{N}$ deposition alone is less important in spruce and beech than in oak plots. The values produced under the FN scenario ranged between the FN-FC and baseline scenarios. Thus, $\mathrm{CO}_{2}$ fertilization had a strong impact on the increments of spruce and beech. It is noteworthy that the values of the baseline scenario were different from those of the other scenarios.

\subsubsection{Simulation of 60 to $90 \mathrm{yr}$ old stands with constant and dynamic mortality (Design 2)}

A mainly positive tendency was found for stem and root increments for all 3 species (Table 3). For oak, stem and root increments in the near future responded differently to climate change under assumptions of constant and dynamic mortality, although the incre- ments were very similar to one another during the reference and distant future (Fig. 5). Stem and root increments were projected to increase in the distant future by $\sim 40 \%$ relative to the reference period. In the case of beech, stem and root increments were projected to moderately increase, and to increase by $\sim 14 \%$ in the distant future relative to the reference period. In the case of spruce, simulation with dynamic mortality indicated stable stem and root increments, while the simulation using constant mortality indicated an increase in stem and root increments of $\sim 25 \%$ in the distant future.

The magnitudes of GPP and $\mathrm{R}_{\text {eco }}$ were projected to increase for all 3 species, both with constant and dynamic mortality. Net $\mathrm{C}$ uptake showed a tendency to increase for all 3 sites (indicated by more negative values of future NEE). Except for oak simulations under the assumption of dynamic mortality, where $C$ sequestration was projected to increase in the near future and decrease in the distant future, all other simulations showed a tendency toward increasing $\mathrm{C}$ sequestration.

\subsection{Model comparison}

During the reference period, the outputs produced by SIBYLA and BIOME-BGC were relatively similar for 


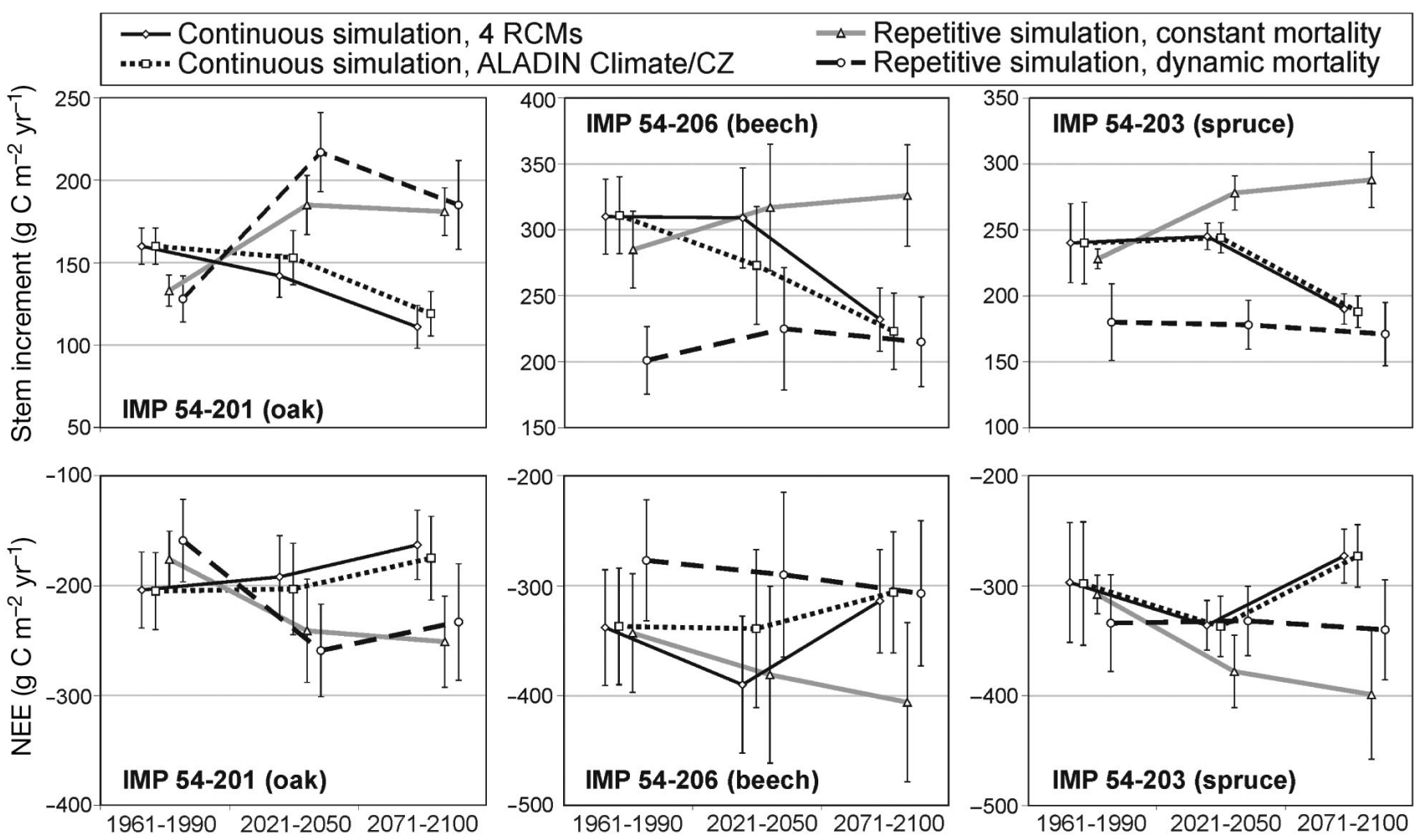

Fig. 5. Average stem increment $\left(\mathrm{g} \mathrm{C} \mathrm{m}^{-2} \mathrm{yr}^{-1}\right)$ and net carbon flux (NEE; $\left.\mathrm{g} \mathrm{C} \mathrm{m}^{-2} \mathrm{yr}^{-1}\right)$ for the reference period, near future, and distant future climates for stands developing continuously from the first half of the 20th century to 2100 (continuous simulation), as well as for stands at age 60 at the beginning of each simulation period (repetitive simulation). Error bars: SD

the relative growing stock increment of oak and spruce (Fig. 6). For beech, the predicted relative growing stock increment was greater with SIBYLA than with BIOMEBGC. Such results suggest that projected absolute values are less certain for beech than for spruce and oak.

The average trends in relative change for the growing stock and total volume production indicated that oak production is not very vulnerable to climate change, because both models showed either balanced or improving forest stand development in the future. For beech, the relative growing stock increment was estimated by both models to decrease to different degrees, while results of simulations of total volume production were contradictory (BIOME-BGC indicated an increase while SIBYLA indicated a decrease). For spruce, BIOME-BGC simulations with dynamic mortality were inconsistent with other simulations. The 2 remaining simulations-BIOME-BGC with constant mortality and SIBYLA-indicated similar relative net increment in the near-future climate, while the output of these models for the distant future were contradictory in that SIBYLA showed an increasing trend while BIOME-BGC showed a decreasing trend for relative net increment. These 2 simulations were highly consistent with respect to the development of total volume production by spruce. Based on this consistency, spruce production at its present ecological optimum seems likely to increase in the future.

\section{DISCUSSION}

\subsection{Limitations}

Some limitations had to be imposed on the experimental design to make the analysis feasible. While the design of growth simulations covered a large part of the distribution range of oak, beech and spruce, the simulations related to the $\mathrm{C}$ cycle covered only the approximate ecological optima of these species. At these locations, the responses to climate change are not expected to be critical. Although climate change can affect forest growth and $\mathrm{C}$ balance by altering the frequency, intensity, duration, and timing of forest disturbances (Dale et al. 2001), factors such as fire, drought, introduced species, and insect and pathogen outbreaks were not considered. Additionally, no forest management alternatives to natural stand development were considered, although the influence of various thinning and harvesting techniques can profoundly affect forest 


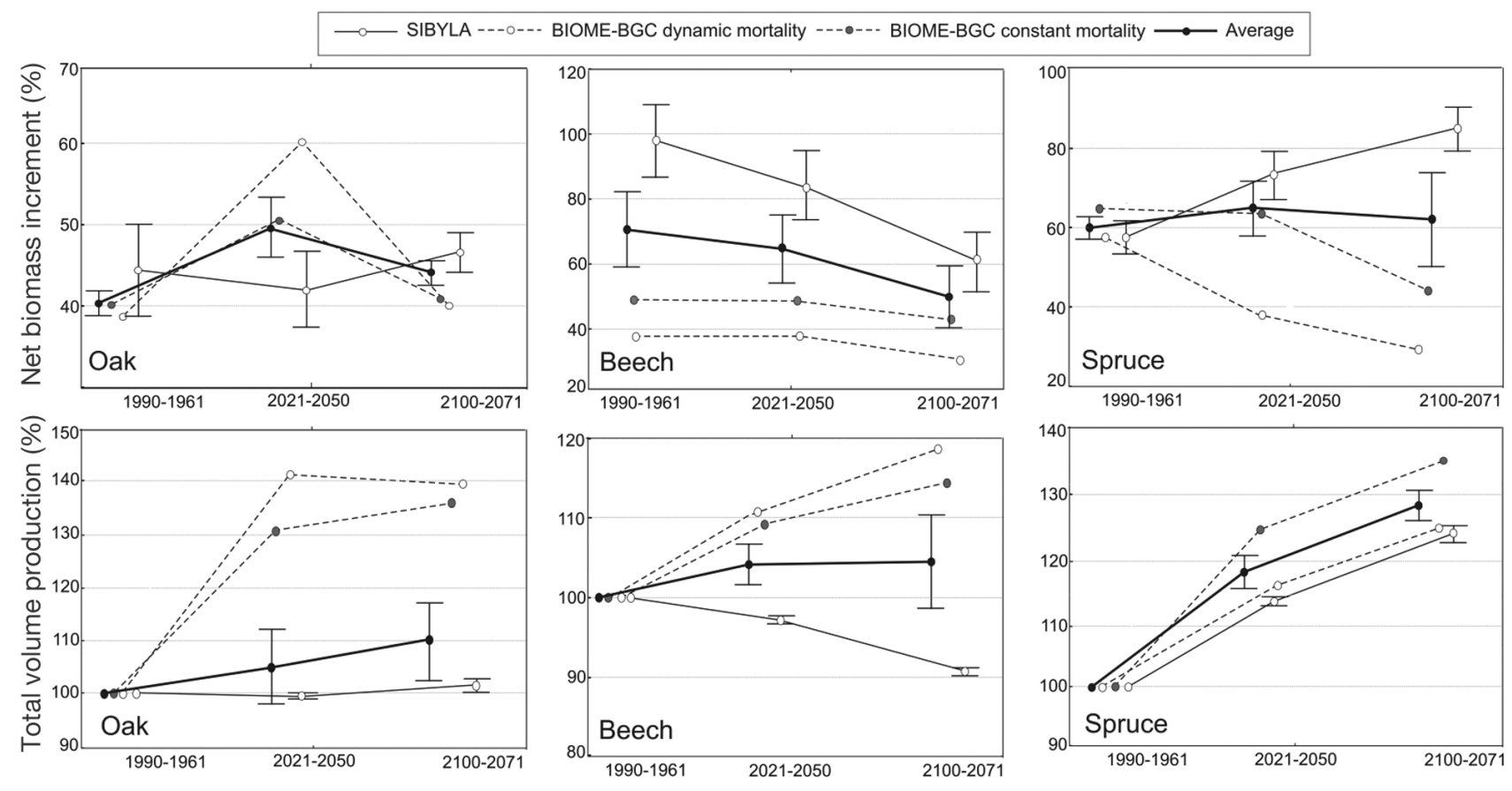

Fig. 6. Relative values of total volume production (future climate vs. reference period) and change in growing stock produced by the SIBYLA tree growth simulator and BIOME-BGC model under ALADIN Climate/CZ climate change scenario. Weighted average of these simulations is presented as well. Error bars: SD

stand biomass and tree vitality under changing climate (Lindner 2000). Without these simplifications, an unwieldy number of possible alternatives would have been generated. Hence, our results represent a baseline scenario of future forest development.

\subsection{Response patterns}

The forest growth simulations indicated significant changes in the production and natural mortality of spruce and beech in response to changing climate in Central Europe. Oak, however, was found to be insensitive to climate change in this region. Because a steep elevation gradient greatly affects plant distribution in the study area, a shift of production optima to higher elevations and a drought-induced production decline at lower elevations were the main patterns generated by the growth simulations. By using altitude-forlatitude models of temperature similarity (Jump et al. 2009), the observed altitudinal shifts can be transferred to corresponding latitudinal shifts.

The C cycle simulations, which were performed in the zone of present ecological optima for each species, indicated that $\mathrm{C}$ sequestration in forests that were planted in the first half of the 20th century can be expected to decrease until the end of the 21st century relative to the reference period. This reflects the change in NPP to GPP ratio over the course of stand development (Mäkelä \& Valentine 2001), which is further modulated by changing environmental parameters. The average response of all investigated species indicated that the relative net growing stock increment during three $30 \mathrm{yr}$ simulation periods will decrease from $65 \%$ in the reference period to $15 \%$ in the distant future (stand development from 60 to $175 \mathrm{yr}$ ).

The 30 yr simulations starting at stand age 60 in 1961, 2021, and 2071 suggested generally positive effects of climate change on $\mathrm{C}$ sequestration and tree growth for all 3 species, although results obtained under the assumption of dynamic mortality showed less sequestration in the distant future than in the near future (Fig. 5). All C cycle simulations suggested that the investigated ecosystems can be expected to remain net $\mathrm{C}$ sinks in the future (assuming that the forests develop without disturbance), although the magnitude of sequestration capacity differed among the 3 species. Responses to increasing $\mathrm{CO}_{2}$ fertilization and $\mathrm{N}$ deposition differed as well, and these can be considered to be species specific. Overall, the joint impact of elevated $\mathrm{CO}_{2}$ fertilization and $\mathrm{N}$ deposition was projected to increase $\mathrm{C}$ sequestration to some extent.

A multi-model assessment of future forest development suggested balanced or slightly declining relative growing stock increment of the 3 species in the zones of their present ecological optima, while total volume 
production generally increases. The degree to which the output of the 2 models agreed varied markedly among species and among investigated quantities.

\subsubsection{Oak}

Oaks are favoured by relatively warm and dry climates (Lorimer 1993). Hence, most studies on oak responses to climate in Europe come from the Mediterranean (e.g. Sabaté et al. 2002), while knowledge from Central Europe is rather incomplete. As expected, the current study indicated that oak production and mortality were almost insensitive to climate change in Central Europe. Production equal to that in the reference climate and even decreasing mortality in elevations up to $\sim 300 \mathrm{~m}$ a.s.l. suggest sustainability of oak forests in this region. Increasing production in elevations above $400-500 \mathrm{~m}$ a.s.l. by up to $10 \%$ in the future suggests potential expansion of oak distribution upwards, especially on nutrient-poor and drier stands, where oak can successfully compete for resources with the resident species. Climate change is not expected to negatively affect the receding edge of oak forests in Central Europe provided that resident pests and pathogens (e.g. defoliators such as Lymantria dispar L. or tracheomicotic fungi such as species of Ceratocystis and Ophiostoma) do not increase their outbreak ranges (Hlásny \& Turčáni 2009) and virulence, and provided that newly emerging species (Bolte et al. 2009) do not substantially alter the present forest disturbance regime.

C cycle simulations of 60 to $90 \mathrm{yr}$ old oak stands suggested that oak production and net $\mathrm{C}$ uptake will increase in the near future under the assumptions of either constant or dynamic mortality; this trend was projected to remain constant or decrease in the distant future relative to the near future. Our multi-model assessment predicted balanced or slightly increasing relative growing stock increment, while total volume production was projected to rise. The latter, however, is subject to large uncertainty.

The C cycle simulations in this study can be compared with those of Davi et al. (2006), who predicted the future C cycle of Western European forests (the effect of $\mathrm{N}$ deposition was not included). These authors found that net C uptake of a sessile oak (Quercus patraea) stand (Fontainebleau, France, temperate climate, $120 \mathrm{~m}$ a.s.l., 136 yr old) increased from 1960 to 2000, and then, with minor fluctuations, was projected to remain stable until 2100. This finding is consistent with the SIBYLA results in the current study (in terms of stable productivity after 2000), while our BIOME-BGC simulations projected that $C$ uptake will markedly increase in the near future and become stable afterward.
A recent assessment of the impact of climate change, increasing $\mathrm{CO}_{2}$ concentration, and changing $\mathrm{N}$ deposition on $\mathrm{C}$ sequestration of European forests suggested that different oak species would respond differently to climate change (Wamelink et al. 2009); nevertheless, the study estimated that $\mathrm{C}$ sequestration averaged across oak species will increase by $64 \%$ up to 2070 throughout Europe. This corresponds with our BIOMEBGC simulations, which forecast an average increase in C uptake by oak of $50 \%$ up to 2050 (under the assumptions of either dynamic or constant mortality).

\subsubsection{Beech}

Beech is the most abundant native tree in Central Europe (Ellenberg 1996), and it generally plays a central role in current forest transition strategies (Tarp et al. 2000). Beech is a highly plastic and adaptable species, although it becomes climate sensitive close to its xeric distribution limit (Mátyás et al. 2010). Our growth simulations indicated that the beech production optimum will shift in the distant future into a relatively narrow belt around $1200 \mathrm{~m}$ a.s.l. (from the elevation range approximately between 400 and $800 \mathrm{~m}$ a.s.l. under the reference climate) (Fig. 2); thus, the regional production of beech forests can be expected to decline. This agrees with Sykes \& Prentice (1996), who projected that beech and other temperate hardwoods would spread to the north and that climate warming would induce an increased rate of beech establishment as a successional response after disturbances.

In contrast to the projected increase in growth of beech at higher elevations, increased mortality and reduced production were projected to occur in its lower distribution range. Based on future projections of Ellenberg's drought index, Mátyás et al. (2010) suggested that beech at lower elevations in southeastern Europe could survive increasing drought, assuming that extreme events with subsequent pest outbreaks do not occur. This, however, is an unrealistic assumption. Other studies suggested a decline in beech regeneration (Czajkowski et al. 2005, Peñuelas et al. 2007, Lenoir et al. 2009) and an increase in mortality rates as a consequence of prolonged drought (Berki et al. 2009). Simulation under projected climatic change showed that beech could lose competitive ability if drought stress increases (Lindner 2000). Dry and hot weather during summer were also found to strongly reduce net primary production of beech forests (Ciais et al. 2005). This is consistent with our finding of a critical beech decline that was projected to occur in the distant future at elevations approximately up to $500 \mathrm{~m}$ a.s.l. (negative values for the relative change in growing volume in the 1st to $2 \mathrm{nd} \mathrm{VZ}$ in the 
distant future indicate that mortality prevails over the increment).

The potential impacts of such developments on the regional production of beech forests in Slovakia can serve as an example. At present, up to $5 \%$ of beech stands in the country are distributed at elevations where beech mortality can occur, $70 \%$ lie in the zone of declining production (up to $20 \%$ in the distant future), $20 \%$ lie in the zone where production is supposed to be equal to that in the reference period, and only the remaining $5 \%$ lie in the zone of improved production (7th $\mathrm{VZ}$, production improvement by up to $30 \%$ ). However, the latter zone is presently almost free of beech; thus, significant human-assisted expansion of beech's upper distribution range will be needed to allow for the improved production to be realized in the 7th VZ. While the present findings indicate that the potential of beech to help European forests adapt to expected climate change is less than previously expected (e.g. Lindner 2000, Bolte et al. 2009), beech's broad range of natural distribution and relatively low vulnerability to biotic and abiotic agents argue for its broader use, except in locations near its lower distribution limit. Generally, forest management is expected to support further expansion of beech in the conversion of declining spruce forests in Central Europe (Spiecker et al. 2004).

For 60 to $90 \mathrm{yr}$ old stands in the zone of beech's present ecological optimum, beech $\mathrm{C}$ cycle simulations showed continuously increasing $\mathrm{C}$ sequestration by up to $15 \%$ by 2100 ; this increase was projected regardless of whether mortality was assumed to be dynamic or constant. Multi-model assessment projected a slight decline in relative growing stock increment, while total volume production was projected to increase in the near future and remain stable thereafter. Distant future projections were very uncertain, and the models used showed contradictory tendencies.

BIOME-BGC results agree with Davi et al. (2006), who suggested that net $C$ uptake of 2 beech stands (at 300 and 120 m a.s.l.) in Western Europe will generally increase until 2100 with minor fluctuations. The trend of increasing GPP and $R_{\text {eco }}$ reported by Davi et al. (2006) is also consistent with our results (see Table 3). A $69.1 \%$ increase in beech C uptake until 2070 (European mean) was predicted by Wamelink et al. (2009), but this markedly exceeds the 8 to $15 \%$ increase in our simulations.

\subsubsection{Spruce}

Spruce is a highly vulnerable, water-demanding species that is currently distributed largely outside the range of its natural distribution in Central Europe (Ellenberg 1996). Therefore, indirect climate change effects, particularly those acting through changes in forest disturbances, are much more pronounced in spruce than in other species (Eriksson et al. 2005, Schütz et al. 2006). This significantly limits the applicability of spruce growth and $\mathrm{C}$ cycle simulations that have not considered natural and human-induced disturbances. The spruce growth simulations indicated a generic response pattern of declining production at lower elevations and increasing production in spruce's ecologically (but not productively) optimal 7th VZ (1250-1550 m a.s.l.) by the end of the century. Because most spruce stands in Central Europe are distributed at lower elevations (Ellenberg 1996, Spiecker et al. 2004), however, the projected decline in spruce production in the elevation range $400-800 \mathrm{~m}$ a.s.l. could result in a significant decrease in forest biomass in the future; this decline would occur mainly in the Czech Republic, Slovakia, Poland and Germany, where spruce has been widely planted outside the narrow mountain range that represents its original distribution. In Slovakia, for example, $9 \%$ of all spruce stands are distributed at elevations where spruce production was projected to rise, while $20 \%$ of spruce stands are at elevations where production was expected to decline significantly. Production of the remaining spruce stands was projected to remain more or less equal to that in the reference period. Spruce growth and survival at these elevations, however, could be threatened by future development of a 3rd generation of the spruce bark beetle (Ips typographus) (Hlásny et al. 2011), as well as by increasing drought stress that would enhance spruce susceptibility to secondary agents (Dutilleul et al. 2000). Thus, spruce is not expected to be sustained there. Bergh et al. (2003) suggested that spruce forests in Scandinavia will probably increase their productivity if they are not greatly damaged by increased bark beetle attacks.

BIOME-BGC simulations with dynamic mortality predicted relatively stable growing stock increments and C uptake by spruce up to 2100 , while these quantities were projected to increase under the assumption of constant mortality. Multi-model assessment based on SIBYLA and BIOME-BGC simulations showed a balanced relative growing stock increment and a continuous increase in total volume production with small uncertainty. Wamelink et al. (2009) suggested that $\mathrm{C}$ sequestration for Norway spruce in Europe could increase by $57.9 \%$ until 2070 . The BIOME-BGC simulations showed the same tendency, although the projected increase is smaller (11 and $15 \%$ in the near and distant future, respectively). Regarding future development of mountain spruce forests in Central Europe, Wieser et al. (2009) projected GPP to rise in the European Alps by $\sim 15 \%$ assuming an increase in mean annual temperature of $1.0^{\circ} \mathrm{C}$, thus causing net eco- 
system production $(\mathrm{NEP}=-\mathrm{NEE})$ to be enhanced by $5 \%$ relative to the present situation. This corresponds well with our SIBYLA projections of a $\sim 17 \%$ increase in spruce production in the near future (with $\sim 1.7^{\circ} \mathrm{C}$ regional temperature increase) in the mountain zone and an increase in NEP by as much as $11 \%$ (average of BIOME-BGC simulations with constant and dynamic mortality). Hence, our simulations corroborate projections that $\mathrm{C}$ sequestration of timberline forest ecosystems could increase in the future and that such ecosystems could act as important C sinks (Bergh \& Linder 1999, Zha et al. 2004).

\subsection{Concluding remarks}

The BIOME-BGC and SIBYLA simulations presented in this paper showed remarkable differences in model output. This appears to be a general problem of such modelling (e.g. see the conflicting results of Karjalainen et al. 2003, Davi et al. 2006, and Wamelink et al. 2009). The discrepancies presented emphasize the need for multi-model assessment of future forest development in order to clarify and highlight differences in model assumptions and model sensitivities to environmental and human interventions.

There is a growing need for the use of multi-model ensemble estimations for both present day forest productivity and $\mathrm{C}$ sequestration (Ťupek et al. 2010) as well as for climate change impact studies (Eggers et al. 2008). Empirical forest growth models, such as the SIBYLA tree growth simulator, are mostly based on regression analysis-adapted growth curves concerning the relationships between age and height for different site conditions (Pretzsch 2009). Empirical growth models are capable of producing reliable outputs even under different climate change scenarios (Matala et al. 2005), forest management (Lindner 2000), or atmospheric pollution (Špulák \& Souček 2010). Such models are generally based on the conservation of climatic envelopes for species but they ignore the capacity of populations to modify their ecological niches in the future (Thuiller et al. 2006). Process-based models, such as BIOME-BGC, focus on the proper description of fundamental physiological and biogeochemical processes, but they may lack predictive capabilities during extreme weather conditions (e.g. see Vetter et al. 2008). Despite many simplifications, such as keeping inherently dynamic parameters constant (e.g. the partitioning of $\mathrm{C}$ allocation between aboveground and belowground compartments, or stand mortality) (Palmroth et al. 2006), process-based models deliver broad sets of output variables that forest managers may need to predict future forest development (Pretzsch 2009). Mäkelä \& Valentine (2001) argue that stand-growth models can give correct answers for the wrong reasons, and that statistical calibration of such models should therefore be avoided whenever possible. Instead, values of physiological parameters should come from measurements of the physiological processes themselves.

The projections of tree growth and natural mortality in this study can be used to improve forest management in response to changing climate. The projections can help managers optimize tree species distribution, identify the most vulnerable forest stands, and propose site- and species-specific adaptive measures. In addition, knowledge about changes in $\mathrm{C}$ sequestration capacity of forests can indicate ways in which forests could be more effectively used to mitigate climate change.

This study fills a gap in our understanding of how climate change will affect the growth and $\mathrm{C}$ cycle of Central European forests with emphasis on 3 tree species that are widespread in the region. The multi-model approach used in this study yielded more robust estimates of stand development than a single-model approach, but the study also demonstrated that there is substantial uncertainty associated with such modelling. An important challenge for interdisciplinary ecological research is to refine the parameterisations of forest models so as to establish a solid basis for robust multi-model assessment of future forest development.

Acknowledgements. This study was conducted as part of the FP6 project CECILIA (Central and Eastern Europe Climate Change Impacts and Vulnerability Assessment) and the project of the Ministry of Agriculture of the Czech Republic No. QH91097. The European Union and the European Social Fund provided financial support to the project under grant agreement no. TAMOP 4.2.1/B-09/1/KMR-2010-0003. BIOME-BGC version 4.1.1 was provided by the Numerical Terradynamic Simulation Group at the University of Montana, which assumes no responsibility for the proper use of BIOME-BGC by others. Data from intensive monitoring plots of the panEuropean forest monitoring programmes (ICP Forests / Forest Focus / FutMon) were used for modelling related to the carbon cycle. We thank A. Horányi, P. Szabó, and D. Hidy (Hungarian Meteorological Service); C. Torma, J. Bartholy, and A. Kern (Eötvös Loránd University); M. Belda (Charles University in Prague); and P. Skalák and P. Štěpánek (Czech Hydrometeorological Institute) for their help.

\section{LITERATURE CITED}

Ainsworth EA, Long SP (2005) What have we learned from 15 years of free-air $\mathrm{CO}_{2}$ enrichment (FACE)? A meta-analytic review of the responses of photosynthesis, canopy properties and plant production to rising $\mathrm{CO}_{2}$. New Phytol 165: 351-372

Barcza Z, Haszpra L, Somogyi Z, Hidy D and others (2009) Estimation of the biospheric carbon dioxide balance of Hungary using the BIOME-BGC model. Idöjárás - Q J Hung Meteorol Serv 113:203-219

Bartholy J, Pongrácz R, Gelybó G (2007) Regional climate 
change expected in Hungary for 2071-2100. Appl Ecol Environ Res 5:1-17

Battles JJ, Robards T, Das A, Waring K and others (2006) Climate change impact on forest resources. Res Rep, California Climate Change Center, CEC-500-2005-193-SF

Bergh J, Linder S (1999) Effects of soil warming during spring on photosynthetic recovery in boreal Norway spruce stands. Glob Change Biol 5:245-253

Bergh J, Freeman M, Sigurdsson B, Kellomäki S and others (2003) Modelling the short-term effects of climate change on the productivity of selected tree species in Nordic countries. For Ecol Manage 183:327-340

Berki I, Rasztovits E, Móricz N, Mátyás Cs (2009) Determination of the drought tolerance limit of beech forests and forecasting their future distribution in Hungary. Cereal Res Commun 37:613-616

Bolte A, Ammer C, Löf M, Madsen P and others (2009) Adaptive forest management in Central Europe: climate change impacts, strategies and integrative concept. Scand J For Res 24:473-482

Bürger G (1997) On the disaggregation of climatological means and anomalies. Clim Res 8:183-194

Christensen JH, Hewitson B, Busuioc A, Chen A and others (2007) Regional climate projections. In: Solomon S, Qin D, Manning M, Chen Z and others (eds) Climate change 2007: the physical science basis. Contribution of Working Group I to the Fourth Assessment Report of the Intergovernmental Panel on Climate Change. Cambridge University Press, Cambridge

$>$ Churkina G, Tenhunen J, Thornton P, Falge EM and others (2003) Analyzing the ecosystem carbon dynamics of four European coniferous forests using a biogeochemistry model. Ecosystems 6:168-184

Churkina G, Brovkin V, von Bloh W, Trusilova K and others (2009) Synergy of rising nitrogen depositions and atmospheric $\mathrm{CO}_{2}$ on land carbon uptake moderately offsets global warming. Global Biogeochem Cycles 23:GB4027 doi:10.1029/2008GB003291

- Ciais P, Reichstein M, Viovy N, Granier A and others (2005) Europe-wide reduction in primary productivity caused by the heat and drought in 2003. Nature 437:529-533

Cienciala E, Tatarinov FA (2006) Application of BIOME-BGC model to managed forests. 2. Comparison with long-term observations of stand production for major tree species. For Ecol Manag 237:252-266

Colwell RK, Brehm G, Cardelús CL, Gilman AC, Longino JT (2008) Global warming, elevational range shifts, and lowland biotic attrition in the wet tropics. Science 322: 258-261

Courtier P, Freydier C, Geleyn JF, Rabier F, Rochas M (1991) The ARPEGE Project at Météo-France. Proc ECMWF Seminar, Vol 7. ECMWF, Shinfield, Reading, UK, p 193-231

Crimmins SM, Dobrowski SZ, Greenberg JA, Abatzoglou JT, Mynsberge AR (2011) Changes in climatic water balance drive downhill shifts in plant species' optimum elevations. Science 331:324-327 doi:10.1126/science.1199040

Czajkowski T, Kuhling M, Bolte A (2005) Einfluss der Sommertrockenheit im Jahre 2003 auf das Wachstum von Naturverjüngungen der Buche (Fagus sylvatica L.) im nordöstlichen Mitteleuropa. Allg Forst Jagdztg 176:133-143

Dale VH, Joyce LA, McNulty S, Neilson RP and others (2001) Climate change and forest disturbances. Bioscience 51: 723-734

> Davi H, Dufrêne E, Francois C, Le Maire G and others (2006) Sensitivity of water and carbon fluxes to climate changes from 1960 to 2100 in European forest ecosystems. Agric For Meteorol 141:35-56
Dentener FJ (2006) Global maps of atmospheric nitrogen deposition, 1860, 1993, and 2050. Data set. Oak Ridge National Laboratory Distributed Active Archive Center, Oak Ridge, TN; available at daac.ornl.gov

De Vries W, Posch M (2011) Modelling the impact of nitrogen deposition, climate change and nutrient limitations on tree carbon sequestration in Europe for the period 1900-2050. Environ Pollut (in press)

De Vries W, Solberg S, Dobbertin M, Sterba H and others (2009) The impact of nitrogen deposition on carbon sequestration by European forests and heathlands. For Ecol Manag 258:1814-1823

Ďurský J (1997) Modellierung der Absterbeprozesse in Reinund Mischbeständen aus Fichte und Buche. Allg Forst Jagdztg 168:131-134

Ďurský J, Škvarenina J, Min áš J, Miková A (1996) Regional analysis of climate change impact on Norway spruce (Picea abies L. Karst.) growth in Slovak mountain forests. J Sci 52:306-331

> Dutilleul P, Nef L, Frigon D (2000) Assessment of site characteristics as predictors of the vulnerability of Norway spruce (Picea abies Karst.) stands to attack by Ips typographus L. (Col., Scolytidae). J Appl Entomol 124:1-5

Eggers J, Lindner M, Zudin S, Zaehle S (2008) Impact of changing wood demand, climate and land use on European forest resources and carbon stocks during the 21st century. Glob Change Biol 14:2288-2303

Ellenberg H (1996) Vegetation Mitteleuropas mit den Alpen, 5th edn. Ulmer, Stuttgart

Eriksson M., Pouttu A, Roininen H (2005) The influence of windthrow area and timber characteristics on colonization of wind-felled spruces by Ips typographus (L.). For Ecol Manag 216:105-116

Fabrika M, Ďurský J (2005) Algorithms and software solution of thinning models for SIBYLA growth simulator. J Sci 51: 431-445

Fabrika M, Ďurský J (2006) Implementing tree growth models in Slovakia. In: Hasenauer H (ed) Sustainable forest management. Growth models for Europe. Springer Berlin, Heidelberg, New York

Geßler A, Keitel C, Kreuyzwieser J, Matyssek R, Seiler W, Rennenberg H (2007) Potential risks for European beech (Fagus sylvatica L.) in a changing climate. Trees (Berl) 21: $1-11$

Gimmi U, Wohlgemut T, Rigling A, Hoffmann CW, Burgi M (2010) Land-use and climate change effects in forest compositional trajectories in a dry central-alpine valley. Ann Sci 67 doi:10.1051/forest/2010026

Giorgi F, Coppola E (2007) European climate-change oscillation (ECO). Geophys Res Lett 34:L21703 doi:10.1029/ 2007 GL031223

Goldblum D, Rigg LS (2005) Tree growth response to climate change at the deciduous-boreal forest ecotone, Ontario, Canada. Can J For Res 35:2709-2718

Hlásny T, Turčáni M (2009) Insect pests as climate change driven disturbances in forest ecosystems. In: Střelcová $\mathrm{K}$, Mátyás C, Kleidon A, Lapin M, Matejka F, Blaženec M, Škvarenina J, Holécy J (eds) Bioclimatology and natural hazards. Springer, New York

Hlásny T, Zajíčková L, Turčáni M, Holuša J, Sitková Z (2011) Geographical variability of spruce bark beetle development under climate change in the Czech Republic. J For Sci 57:242-249

Hollinger DY, Richardson AD (2005) Uncertainty in eddy covariance measurements and its application to physiological models. Tree Physiol 25:873-885

Jump AS, Hunt JM, Penuelas J (2006) Rapid climate change- 
related growth decline at the southern range edge of Fagus sylvatica. Glob Change Biol 12:2163-2174

Jump AS, Mátyás C, Peñuelas J (2009) The altitude-forlatitude disparity in the range retractions of woody species. Trends Ecol Evol 24:694-701

Kahn M (1994) Modellierung der Höhenentwicklung ausgewählter Baumarten in Abhängigkeit vom Standort. Forstl Forschber, Vol 141. Forstwissenschaftliche Fakultät der Universität München und der Bayer Forstlichen Versuchs- und Forschungsanstalt, München

Karjalainen T, Pussinen A, Liski J, Nabuurs GJ, Eggers T, Lapveteläinen T, Kaipainen T (2003) Scenario analysis of the impacts of forest management and climate change on the European forest sector carbon budget. For Policy Econ 5:141-155 doi:10.1016/S1389-9341(03)00021-2

Keeling CD, Whorf TP (2004) Atmospheric $\mathrm{CO}_{2}$ concentrations-Mauna Loa Observatory, Hawaii, 1958-2003 (revised June 2004). NDP-001. Carbon Dioxide Information Analysis Center, Oak Ridge National Laboratory, Oak Ridge, TN

Kienast F, Brzeziecki B, Wildi O (1996) Long-term adaptation potential of Central European mountain forests to climate change: a GIS-assisted sensitivity assessment. For Ecol Manage 80:133-153

Lenihan JM, Drapek R, Bachelet D, Neilson RP (2003) Climate change effects on vegetation distribution, carbon, and fire in California. Ecol Appl 13:1667-1681

Lenoir J, Gégout JC, Pierrat JC, Bontemps JD, Dhote JF (2009) Differences between tree species seedling and adult altitudinal distribution in mountain forests during the recent warm period (1986-2006). Ecography 32:765-777

Lexer MJ, Hönninger K, Scheifinger H, Matulla C, Groll N, Kromph-Kolb H (2000) The sensitivity of Central European mountain forests to scenarios of climatic change: methodological frame for a large-scale risk assessment. Silva Fenn 34:113-129

Lindner M (2000) Developing adaptive forest management strategies to cope with climate change. Tree Physiol 20: 299-307

Lindner M, Maroschek M, Netherer S, Kremer A and others (2010) Climate change impacts, adaptive capacity, and vulnerability of European forest ecosystems. For Ecol Manag 259:698-709

Link WA, Barker RJ (2006) Model weights and the foundations of multimodel inference. Ecology 87:2626-2635

Lorimer CG (1993) Causes of oak regeneration problems. In: Loftis DL, McGee CE (eds) Oak regeneration: serious problems, practical recommendations. Gen Tech Rep SE-84. US Department of Agriculture, Forest Service, Southeastern Forest Experiment Station, Asheville, NC, p 14-39

Magnani F, Mencuccini M, Borghetti M, Berbigier P and others (2007) The human footprint in the carbon cycle of temperate and boreal forests. Nature 447:849-851

Mäkelä A, Valentine HT (2001) The ratio of NPP to GPP: evidence of change over the course of stand development. Tree Physiol 21:1015-1030

- Matala J, Hynynen J, Miina J, Ojansuu R and others (2003) Comparison of a physiological model and a statistical model for prediction of growth and yield in boreal forests. Ecol Modell 161:95-116

Matala J, Ojansuu R, Peltola H, Sievänen R, Kellomäki S (2005) Introducing effects of temperature and $\mathrm{CO}_{2}$ elevation on tree growth into a statistical growth and yield model. Ecol Modell 181:173-190

Mátyás Cs, Berki I, Czúc B, Gálos B, Móricz N, Rasztovits E (2010) Future of beech in Southeast Europe from the per- spective of evolutionary ecology. Acta Silv Lign Hung 6: 91-100

Mitchell T, Carter TR, Jones PD, Hulme M, New M (2004) A comprehensive set of high-resolution grids of monthly climate for Europe and the globe: the observed record (1901-2000) and 16 scenarios (2001-2100). Work Pap 55, Tyndall Centre

Morales P, Hickler T, Rowell DP, Smith B, Sykes MT (2007) Changes in European ecosystem productivity and carbon balance driven by Regional Climate Model output. Glob Change Biol 13:108-122

Nakicenovic N, Swart R (eds) (2000) Special report on emission scenarios. Cambridge University Press, Cambridge

> Norby R, DeLucia E, Gielen B, Calfapietra C and others (2005) Forest response to elevated $\mathrm{CO}_{2}$ is conserved across a broad range of productivity. Proc Natl Acad Sci USA 102: 18052-18056

Palmroth S, Oren R, McCarthy HR, Johnsen KH and others (2006) Aboveground sink strength in forests controls the allocation of carbon below ground and its $\left[\mathrm{CO}_{2}\right]$-induced enhancement. Proc Natl Acad Sci USA 103:19362-19367

Peñuelas J, Ogaya R, Boada M, Jump AS (2007) Migration, invasion and decline: changes in recruitment and forest structure in a warming-linked shift of European beech forest in Catalonia (NE Spain). Ecography 30: 829-837

Pietsch SA, Hasenauer H, Thornton PE (2005) BGC-model parameters for tree species growing in central European forests. For Ecol Manage 211:264-295

Pretzsch H (2009) Forest dynamics, growth and yield. Springer, Berlin

Pretzsch H, Kahn M (1998) Konzeption und Konstruktion des Wuchsmodells SILVA 2.2-Methodische Grundlagen. Abschlußbericht Projekt W 28, Teil 2, München

Rivas-Martínez S, Penas A, Díaz TE (2004) Bioclimatic map of Europe, bioclimates. Cartographic Service, University of León, Spain

Roeckner E, Bäuml G, Bonaventura L, Brokopf R and others (2003) The atmospheric general circulation model ECHAM-5. Part I: model description. Tech Rep 349, MPI for Meteorology, Hamburg

Sabaté S, Gracia CA, Sánchez A (2002) Likely effects of climate change on growth of Quercus ilex, Pinus halepensis, Pinus pinaster, Pinus sylvestris and Fagus sylvatica forests in the Mediterranean region. For Ecol Manag 62:23-37

Schär C, Vidale PL, Lüthi D, Frei C, Häberli C, Liniger MA, Appenzeller C (2004) The role of increasing temperature variability in European summer heatwaves. Nature 427 : $332-336$

Schütz JP, Götz M, Schmid W, Mandallaz D (2006) Vulnerability of spruce (Picea abies) and beech (Fagus sylvatica) forest stands to storms and consequences for silviculture. Eur J For Res 125:291-302

Spiecker H, Hansen J, Klimo E, Skovsgaard JP, Sterba H, von Teuffel K (eds) (2004) Norway spruce conversionoptions and consequences. Brill, Leiden

Špulák O, Souček J (2010) The Sibyla model and development of beech forests affected by air pollution. Cent Eur J Biol 5:371-383

Sykes MT, Prentice IC (1996) Climate change, tree species distributions and forest dynamics: a case study in the mixed conifer/northern hardwoods zone of northern Europe. Clim Change 34:161-177

Tarp P, Helles F, Holten-Andersen P, Larsen JB, Strange N (2000) Modelling near-natural silvicultural regimes for beech-an economic sensitivity analysis. For Ecol Manage 130:187-198

Tatarinov FA, Cienciala E (2006) Application of BIOME-BGC 
model to managed forests. 1. Sensitivity analysis. For Ecol Manag 237:267-379

Thornton PE, Running SW (1999) An improved algorithm for estimating incident daily solar radiation from measurements of temperature, humidity, and precipitation. Agric For Meteorol 93:211-228

Thuiller W, Lavorel S, Sykes MT, Araújo MB (2006) Using niche-based modelling to assess the impact of climate change on tree functional diversity in Europe. Divers Distrib 12:49-60

Trusilova K, Trembath J, Churkina G (2009) Parameter estimation and validation of the terrestrial ecosystem model BIOME-BGC using eddy-covariance flux measurements. Tech Rep 16, MPI for Biogeochemistry, Jena

Tupek B, Zanchi G, Verkerk PJ, Churkina G, Viovy N, Hughes JK, Lindner M (2010) A comparison of alternative modelling approaches to evaluate the European forest carbon fluxes. For Ecol Manag 260:241-251

Valle D, Staudhammer CL, Cropper WP, Gardingen PR (2009) The importance of multimodel projections to assess uncertainty in projections from simulation models. Ecol Appl 19: 1680-1692

Vetter M, Churkina G, Jung M, Reichstein M and others (2008) Analyzing the causes and spatial pattern of the European 2003 carbon flux anomaly using seven models.

Editorial responsibility: Helmut Mayer, Freiburg, Germany
Biogeosciences 5:561-583

Walther GR (2003) Plants in a warmer world. Perspect Plant Ecol Evol Syst 6:169-185

> Walther GR, Post E, Convey P, Menzel A and others (2002) Ecological responses to recent climate change. Nature 416:389-395

Wamelink GWW, Wieggers HJJ, Reinds GJ, Kros J, MolDijkstra JP, van Oijen M, de Vries W (2009) Modelling impacts of changes in carbon dioxide concentration, climate and nitrogen deposition on carbon sequestration by European forests and forest soils. For Ecol Manag 258: 1794-1805

White MA, Thornton PE, Running SW, Nemani RR (2000) Parameterization and sensitivity analysis of the BIOMEBGC terrestrial ecosystem model: net primary production controls. Earth Interact 4:1-85

Wieser G, Matyssek R, Luzian R, Zwerger P, Pindur P, Oberhauber W, Gruber A (2009) Effects of atmospheric and climate change at the timberline of the Central European Alps. Ann For Sci 66:402 doi:10.1051/forest/2009023

Zha T, Kellomaki S, Wang KY, Rouvien I (2004) Carbon sequestration and ecosystem respiration for 4 years in a Scots pine forest. Glob Change Biol 10:1492-1503

Zlatník A (1976) Lesnická fytocenologie. Státní zem delské nakladatelství, Praha

Submitted: October 25, 2010; Accepted: June 16, 2011

Proofs received from author(s): July 30, 2011 